21 Prager K, Malin H, Spiegler D, Van Natta P, Placek PJ. Smoking and drinking behavior before and during pregnancy of married mothers of live-born infants and stillborn infants. Public Health Rep 1984;99:117-27.

22 Fingerhut LA, Kleinman JC, Kendrick JS. Smoking before, during, and after pregnancy. Am 7 Public Health before, during,
1990;80:541-4.

23 Cnattingius S, Lindmark G, Meirik O. Who continues to smoke while pregnant? $\mathcal{F}$ Epidemiol Community Health 1992;46:218-21.

24 Bonati M, Fellin G. Changes in smoking and drinking behaviour before and during pregnancy in Italian mothers: implications for public health intervention. Int $\mathcal{f}$ Epidemiol 1991;20:927-31.

25 Johnson SF, McCarter RJ, Ferencz CH. Changes in alco- hol, cigarette, and recreational drug use during pregnancy: implications for intervention. Am $\mathcal{f}$ Epidemio 1987;126:695-702

26 Pierce JP, Fiore MC, Novotny TE, et al. Trends in cigarette smoking in the United States-educational differences are increasing. $\mathcal{F} A M A 1989 ; 261: 56-60$.

27 Pierce JP. Progress and problems in international public health efforts to reduce tobacco usage. Ann Rev Publ Health 1991;12:383-400.

28 Baker RJ, Nelder JA. The GLIM system, release 3. Generalized linear interactive modelling. Oxford: Numerical Algorithms Group.

29 Walpole I, Zubrick S, Pontré J. Is there a fetal effect with low to moderate alcohol use before or during pregnancy? f Epidemiol Community Health 1990;44:297-301.

\title{
John A Ryle on "social medicine" and "public health" (1948)1
}

PREVENTION OR CURE (50 YEARS ON)?

"For a very long time we have accepted the old adage 'Prevention is better than cure'. In our new era the belief in it - for of its truth there can be no doubt - must remain ever more manifest in our research and its directives and in our teaching. The most conspicuous interest. of the student ten or twenty years hence will, I hope, no longer be in the rare or difficult and too often incurable case, but in the common and more understandable and preventable disease. May the daily questions on his lips become not 'What is the treatment?' but 'What are the causes?' and 'If preventable, then why not prevented?" "

"The study of the ultimate causes of disease - the procatarctic causes without which the specific factors can never find their opportunity - goes hand in hand with the study of the causes of health, and how much we have still to learn of the meaning and measurement. When social pathology and hygiology come into their own we may witness a return - but this time with fuller scientific authority for the guidance of the people and their teachers and rulers - of that ancient pride in health as a cultural objective which has been largely in abeyance since the days of the old Greek civilization."

"The training of the doctor, which began with observations on and the care of the sick individual, is due now for a great forward stride. Observations on whole communities, whether great or small (or on appropriate samples), and improved health provisions for them, must henceforward become the prior objective. The individual is not likely to suffer neglect in the process, for all communities are composed of individuals. For generations yet we shall doubtless continue to build our costly hospitals and clinics, and require our armies of practitioners and ancillaries, but meanwhile we must at least embark upon the crusade which will end in the steady reduction of waiting-lists and the closure of hospital wards, and which will eventually put the physical, mental, and moral health of peoples before their material wealth. in that crusade whether by our researches, by realistic reforms in teaching, by the better education of the people or direct representations to government - it is our first duty as physicians to explore and prepare the way. ${ }^{11}$

"I submit that we can only do this effectively by electing to pursue the study of social man in sickness and in health as assiduously as we have hitherto pursued the study of individual man in the isolation of the consulting room or the hospital bed, when health has finally passed him by. The quality of our actions and our practice and of our leadership in social reformation will depend, as in the past, on many disciplines, but not least, perhaps, upon the science whose history I have briefly sketched and whose province I have endeavoured to define."

fohn Alfred Ryle (1889-1950) was elected physician to Guy's Hospital, London in 1924 (the Ryle nasogastric tube bears his name). In 1935, he was appointed to the Chair of Physic (internal medicine) in Cambridge, but he returned to work in London during the second world war, until 1943 when he was made Professor of Social Medicine-the first such appointment in the UK. Ryle relinquished one of the largest consulting practices in London to become a pioneer of social and preventive medicine.

1 Ryle JA. Changing disciplines. London: Oxford University Press, 1948. Extracted from quotations in Buck C, Llopis A, Najera E, Terris M. The challenge of epidemiology. Issues and selected readings. Washington; Pan American Health Organization, Regional Office of the WHO, 1989. 